\title{
Multi-criteria assessment of the sustainability of farming systems in the reclaimed desert lands of Egypt
}

\author{
Véronique Alary ${ }^{\mathrm{a}, \mathrm{b}, *}$, Samir Messad ${ }^{\mathrm{b}, \mathrm{d}}$, Adel Aboul-Naga ${ }^{\mathrm{c}}$, Mona A. Osman ${ }^{\mathrm{c}}$, \\ Taha H. Abdelsabourc ${ }^{c}$, Abdel-Aal E. Salah ${ }^{\mathrm{c}}$, Xavier Juanes ${ }^{\mathrm{b}, \mathrm{d}}$ \\ ${ }^{a}$ CIRAD, UMR SELMET, ICARDA, Station Exp. INRA-Quich, Rue Hafiane Cherkaoui. Agdal, B.P. 6299, Rabat, Morocco \\ b SELMET, Univ Montpellier, CIRAD, INRAE, Institut Agro, Montpellier, France \\ ${ }^{\mathrm{c}}$ Animal production Research Institute (APRI)/Agricultural Research Centre (ARC), Nadi El-Said St., Dokki, Giza, Egypt \\ ${ }^{\mathrm{d}}$ CIRAD, UMR SELMET, F-34398 Montpellier, France
}

\section{A R T I C L E I N F O}

\section{Keywords:}

Egypt

Index of sustainability

Integrated crop-livestock systems

Multi-criteria method

Multiple factor analysis

Desert lands

\begin{abstract}
A B S T R A C T
On newly cultivated lands in deserts as in the majority of dryland areas, the sustainability of agricultural systems is often debated in terms of socioeconomic viability and agro-ecological longevity. In these contexts, livestock production systems have raised controversial debates regarding their roles and effects in terms of sustainable development. The objective of this paper is to assess the level (and types) of crop-livestock integration in the dryland systems and whether they result in different well-being and improved efficiency of these agroecosystems. Using an empirical study in the newly reclaimed desert lands of the west part of the Nile Delta (Egypt), we proposed an assessment of the sustainability of the family farming systems using two approaches: a) multiple factor analysis and b) multi-criteria assessment. The multi-criteria assessment highlighted how family farm sustainability depends highly on the integration of livestock into the system, with technical or economic efficiency effects. The multiple factor analysis allowed the distinction of two types of farm systems in which livestock activity could be a source in increasing labour productivity or ensuring the viability of the farm in both short and long terms. So, the two approaches brought out the critical role of livestock in the overall efficiency of the system. However, factor analysis highlighted different profiles of integration and diversification based onfarm assets, and the multi-criteria assessment provided a comprehensive framework for conceptualizing aggregated indicators for the development of sustainable farming systems for the end-users. So these two methods may be complementarity to develop and assess the causal processes of a sustainability assessment.
\end{abstract}

\section{Introduction}

Over the last few decades, livestock production systems have raised an extensive and controversial debate regarding their roles as direct and indirect effects in terms of sustainable development (e.g., Boyazoglu, 1998; Steinfeld et al., 2006; Gerber et al., 2013; Herrero et al., 2015). Notably, during the 1990s and 2000s, pressures on the biomass for animal feed were addressed in terms of competitions regarding resources used (land, water, and nutrients), which could affect overall sustainable development (Dixon et al., 2010). Over the last decade, it has been progressively recognized and demonstrated that the synergies between cropping and livestock husbandry offer many opportunities to increase sustainable production by increasing productivity and resource use efficiency, both in households and territories (Herrero et al., 2010;
Alvarez et al., 2010, 2014; Berre et al., 2017; Leterme et al., 2019). From a socioeconomic perspective, livestock activities have also been considered a part of a livelihood strategy for diversification and intensification processes (Ellis, 1998; Faye and Alary, 2001). The diversification of activities has long been recognized as a means of adaptation of families to harsh environments with high-risk climatic conditions (Reardon et al., 1992, 2000; Ellis, 2000). Diversification can be done by off-farm activities and correlated to the educational level of family members on the farm or their social network and by agricultural activities related to crop and livestock systems. For instance, livestock is frequently associated with the more resilient smallholder family farming systems in the case where crucial assets (mainly physical assets, such as land or natural resources) are limited. More broadly, with the daily tasks of feeding, keeping, or even milking, the livestock activity

\footnotetext{
Abbreviations: TLU, total livestock unit; FWU, family work unit (in full-time jobs); L, linear; C, constant; D, decreasing; I, increasing

* Corresponding author.

E-mail address: veronique.alary@cirad.fr (V. Alary).
} 
generates permanent works, with a limited but entirely secure income (see Sraïri and Ghabiyel, 2017; Alary et al., 2019). Another critical element for sustainable development is to improve efficiency, i.e., produce more food from less land, water, and other resources (Matson et al., 1997; Herrero et al., 2013; Kropps et al., 2019). In this perspective, the ecological intensification process has attracted substantial scientific and developmental interest by integrating nature and ecosystem service provisions into the intensification process (Tittonell, 2014). The challenge was how to produce more with less harm to the environment. Many authors have justified integrated crop-livestock systems in terms of biomass preservation (regarding manure) and crop waste limitation (regarding the feed system) (Herrero et al., 2010; Alvarez et al., 2014).

So, previous research has shown that livestock as an activity of diversification at the farm level improves family economic well-being by sustaining minimum income over time. Besides, the integration of livestock activities into the whole system helps in increasing farm efficiency through biomass preservation and by-product recycling. In the paper, we state the assumption that well-being and efficiency are two aggregate output indicators to assess the overall sustainability of the crop-livestock farming systems. Testing this approach related to the contribution of livestock to sustainability at the household farm level, however, requires developing a set of indicators that represents these four dimensions, i.e., diversification, integration, efficiency, and wellbeing, as a way to consider all these indicators in one framework. Related to sustainability assessment, we observed recent developments and a keen interest in multi-criteria approaches in agricultural model development. Carof et al. (2013) reported seven methods for multicriteria assessment of agrarian system sustainability, based either on a matrix or linear programming models (such as bioeconomic models). In this panel of methods, sustainability depended mainly on the environmental and economic dimensions. The social viability that is a significant component of sustainability linked with the social network and capital is rarely addressed (von Wirén-Lehr, 2001). Another difficulty in assessing sustainability is the determination of the relative importance of each variable, which reflects trade-offs among the main dimensions of sustainability, i.e., economic, environmental, and social.

In the present work, our main research objective was to understand and assess the level (and types) of crop-livestock integration and diversification in the dryland systems and whether they result in different well-being and improved efficiency of these agroecosystems. In other words, we sought to determine how the levels of diversification and integration jointly described the overall sustainability of farming systems. In this perspective, the main challenge was to identify and integrate multiple variables that reflect the differential roles of livestock at the farm and household level. We proposed to approach the family well-being by the level of satisfying food requirements and the basic daily needs of the family in the short term, the coverage of annual family and farm expenses in the medium term (associated with annual net income), and the transmissibility of the farm in the long time, i.e., ability to pass the farm to the next generation. In the efficiency assessment, we combined indicators of socioeconomic viability (such as total farm employment and net income) and productivity. Diversification included crop and animal patterns and off-farm activities, and integration resulted from manure and feed flow between crop and livestock activities. So, in our frame, integration, diversification, well-being, and efficiency are four separate dimensions, and our final goal was to understand their interrelations to assess the family farm sustainability, without a priori on the causal processes. To do that, we developed and used two approaches, that is the factor analysis to determine the differential roles of livestock according to the main family assets and the multi-criteria assessment using an indicator assessment tool constructed from many variables. This study was conducted in the newly cultivated desert lands of the western fringe of the Nile Delta, namely New Reclaimed Lands (NRLs) in Egypt. In this zone, we can observe a diversity of roles given to livestock according to the family farm system, the land access and the orientation toward cash crops (like trees) or traditional annual crops like cereals and berseem, and this according to the origin of the settlers (Alary et al., 2018).

\section{Materials and methods}

\subsection{Case study and materials}

The cultivation of desert lands through the extension of canal irrigation has always been considered as one of the agricultural strategies of Egypt to achieve food security in the face of the demographic growth and land fragmentation in the Nile Valley. The development of desert land started early in the 1900s, but this process was accelerated from the end of the 1950s. Currently, the Ministry of Agriculture and Land Reclamation intends to continue this trend to extend the scheme to approximately $4200 \mathrm{~km}^{2}$ in the Western Desert (according to the Sustainable Agricultural Strategy, 2030). However, the debate concerning the best model of attribution of these new lands among private and public investors and smallholders, and the socioecological sustainability of the agricultural systems remain questionable (Nielsen and Adriansen, 2005; Bush, 2007; Malm and Esmailian, 2012; Barnes, 2013; Alary et al., 2018). Concerning the smallholders, the Agricultural Faculty graduates were the first land beneficiaries in the 70ies, as a measure for controlling the unemployment among the new graduates (Adriansen, 2009). Then, progressively, land access has been extended to all faculty graduates, to old land renters that had lost their land as a result of the agrarian reform of 1992, and to women and retirees, called here 'common beneficiaries.'

In our study, we have selected five areas along a chronological gradient of desert land development for cultivation: the old NRLs from the 1960s in southwestern Alexandria (El Nahda), and the newly NRLs of the 1990s (Tiba and Bustan). Between these dates, the other two areas - Banger and El Hammam - cover the intermediate NRLs from the 1980s (Fig. 1). In these five areas, the climate is arid, and they receive an average of $100 \mathrm{~mm}$ of rainfall annually, between December and January, with a mild winter and hot summer (Bishay, 1993). The land development in this zone has been based on the construction and extension of the Nuberia canal and its branches, notably An-Nars canal, for irrigation, and the vast diffusion of the sprinkler systems.

In each of the five areas, three to four villages were chosen to reflect the diversity of land access based on the successive settlement programs. The selected villages and interviewees also represented the diversity of the type of beneficiaries in the NRLs, as described by Alary et al. (2018). In each village, approximately ten family farms were selected, based on the snowball sampling method (Goodman, 1961). Our sample included small (less than 1 ha, representing mainly non-graduates beneficiaries) and medium farms (1-2 ha, representing graduate beneficiaries or new buyers), as well as livestock herd size. Fifteen large family farmers (larger than 4 ha), from different areas, were added to the survey. Only the large farms developed by multinational agro-industrial firms or entrepreneurial firms with salaries were not considered. The total sample included 175 farms surveyed in 2013/2014. The farm household survey was based on a semi-structured questionnaire that included six components: household living conditions, land and cropping systems, livestock structure and management, costs and financial issues, dynamics in the farming system over the time of settlement, and social capital. Integrated crop-livestock systems were dominant in the oldest settled lands, mainly in the El Nahda and Bangar areas in 2014. We can observe an agricultural change from seasonal crops toward trees in the most recent settled lands (i.e., Tiba and Bustan). Table 1 provides a brief overview of the farming systems in the five areas. For each area, we can observe a different combination of roles of livestock between the diversification of activity and accumulation for investment. 


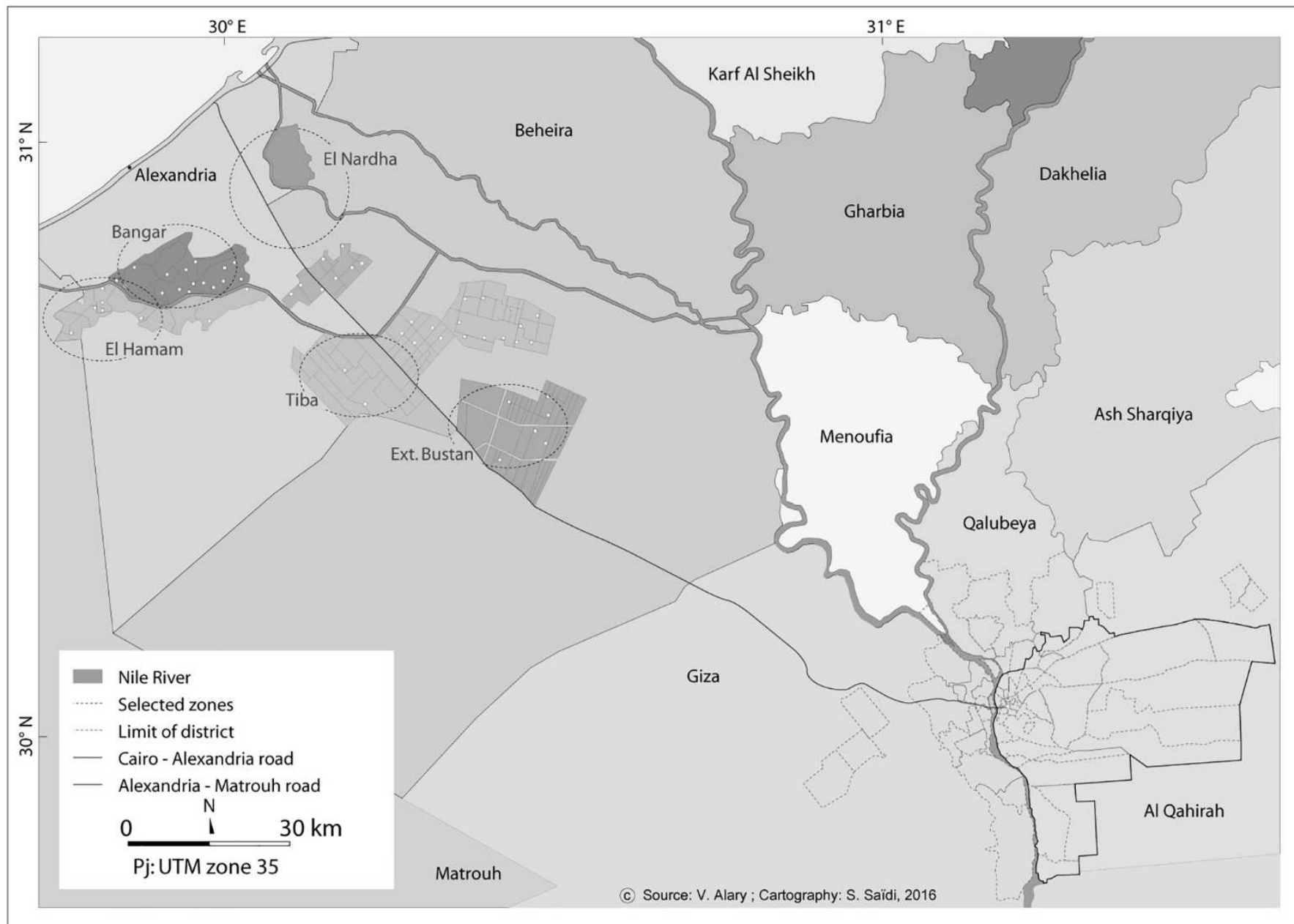

Fig. 1. Geographical location of the five selected areas in the western part of the Nile Delta (Egypt) (Alary et al., 2016, http://agritrop.cirad.fr/584660/).

\subsection{Methods}

\subsubsection{General methodological framework and criteria}

In this paper, our goal was to assess the differential roles of livestock at the family farm level between the five areas of the NRLs in terms of efficiency and well-being, according to a gradient of integration and diversification. To do that, we needed to search for links between the family and farm assets, and the degree of diversification, integration, efficiency, and well-being by area and type of land access (Fig. 2).

In the first step, one of the significant challenges was to identify the primary variables that reflected the different dimensions of sustainability, and that would condition the analysis.

First, based on the traditional approach of farming systems, we defined three groups of variables to describe the family farming systems (Table 2). The theme of 'family' included variables that reflected the educational levels of the family head and his children, and the distribution of human capacity between farm and off-farm activities, according to gender, rate of employment outside the farm, and members seeking employment. The theme of 'land' reflected the land availability and differing access to land tenure. The 'livestock' theme mainly described the composition of the large ruminant herds in terms of size, species, breed of dairy animals, and purpose (fattening or dairy

Table 1

Descriptive statistics for the farm sample in the five studied areas of the newly reclaimed lands (Egypt).

\begin{tabular}{|c|c|c|c|c|c|c|}
\hline Areas & El Nahda & Banger & El-Hammam & Bustan & Tiba & Overall \\
\hline Family size (no of members) & 11.15 & 7.7 & 6.74 & 9.9 & 7.4 & 8.67 \\
\hline Family workers (no of full-time persons) & 3.22 & 3.01 & 2.67 & 3.82 & 3.09 & 3.2 \\
\hline Cultivated area (in ha) & 3.8 & 2.2 & 1.3 & 1.9 & 2.6 & 2.4 \\
\hline Wheat area (in \%) & $16 \%$ & $27 \%$ & $25 \%$ & $16 \%$ & $8 \%$ & $18 \%$ \\
\hline Fodder area (in $\%)^{\mathrm{a}}$ & $43 \%$ & $42 \%$ & $38 \%$ & $29 \%$ & $19 \%$ & $34 \%$ \\
\hline Tree plantation (in \%) ${ }^{\mathrm{a}}$ & $0 \%$ & $1 \%$ & $3 \%$ & $36 \%$ & $67 \%$ & $23 \%$ \\
\hline Other annual crops (in \%) ${ }^{\mathrm{a}}$ & $44 \%$ & $32 \%$ & $33 \%$ & $29 \%$ & $16 \%$ & $30 \%$ \\
\hline Buffalo herd (no of head) & 7.56 & 1.27 & 0.94 & 1.67 & 1.2 & 2.51 \\
\hline Cross bred (no of head) & 7.85 & 5.76 & 3 & 4.67 & 2.31 & 4.73 \\
\hline Local breed bovine (no of head) & 0.65 & 0.79 & 0.55 & 0.62 & 0.09 & 0.54 \\
\hline Dairy cattle (no of head) & 8.56 & 4.61 & 2.65 & 4.19 & 2.03 & 4.41 \\
\hline Sheep and goat (no of head) & 6.35 & 2.03 & 2.87 & 4.43 & 0.57 & 3.3 \\
\hline
\end{tabular}

${ }^{\text {a }}$ Expressed \% of total cultivated area. 


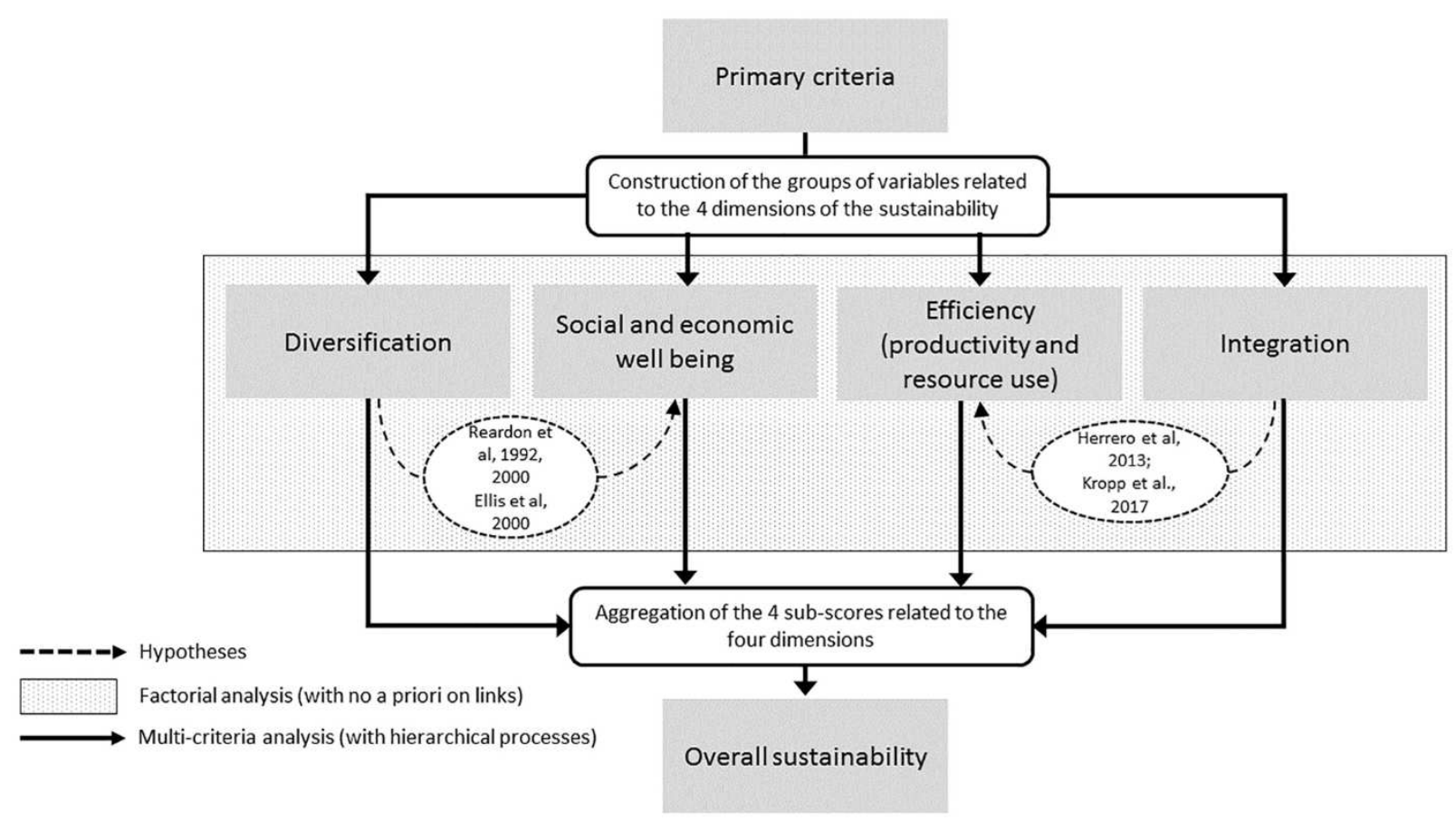

Fig. 2. General framework of the assessment of the sustainability at the family farm level.

Table 2

Variables relating to the main family farm assets - human, land and livestock.

\begin{tabular}{|c|c|c|c|}
\hline Groups & Variables & Label & Thematic \\
\hline \multicolumn{4}{|c|}{ Family Theme } \\
\hline \multirow[t]{8}{*}{ Family } & Education of the head of the family & Edu_H & \multirow[t]{8}{*}{ Human asset based on family size, labour availability and education } \\
\hline & Age of the head of the family & age_head & \\
\hline & Family size & fs_hh & \\
\hline & $\%$ schooled children & per_school & \\
\hline & Children working on the farm & fw_child_nschool & \\
\hline & Potential male and female workers in the family & amw_hh & \\
\hline & Family members working outside the farm & tw_out & \\
\hline & Family members who can work outside the farm & tw_out_pot & \\
\hline \multicolumn{4}{|c|}{ Land Theme } \\
\hline \multirow[t]{5}{*}{ Land } & Total area owned by the family & atot & \multirow[t]{5}{*}{ Land asset based on land access and ownership } \\
\hline & Total cropped area per year & acult & \\
\hline & $\%$ rented land & prent & \\
\hline & Purchased land $\left(\right.$ feddan $\left.^{1}\right)$ & area_purch & \\
\hline & Lands accessed in the settlement program (feddan ${ }^{1}$ ) & area_ben_grad & \\
\hline \multicolumn{4}{|c|}{ Livestock Theme } \\
\hline \multirow[t]{6}{*}{ Livestock } & Number of $\mathrm{TLU}^{2}$ & TLU_farm & \multirow[t]{6}{*}{ Livestock asset based on animal stock and genetic material } \\
\hline & Fattening animals & fat_TLU & \\
\hline & Dairy animals & Dairy_farm & \\
\hline & $\%$ dairy buffalo (per total dairy animals) & perbuff_dairy & \\
\hline & $\%$ dairy crossbreed (per total dairy animals) & percross_dairy & \\
\hline & Small ruminants & SR_head & \\
\hline
\end{tabular}

animals). This theme also included a variable related to the number of small ruminants that could reflect either the need for cash flow or the tradition of a community, like the Bedouin community in the ElHamman area. These three themes allowed differentiating the farm systems according to the main human and physical assets in the studied area.

Second, we defined the four selected dimensions of sustainability considered as the investigated 'themes' (presented in Table 3). We approached the level of diversification through the cropping pattern, the relative importance of livestock cash flow and products in the family income, and the farm labor source (family or outside workers). The level of integration between crops and livestock was based on the feed system (especially the self-produced feed cost per animal unit) and the manure as organic nitrogen on- and off-farm supply. Well-being approach resulted from four groups of variables related to (i) income generation per family worker and family member; (ii) the animal product contribution to family food security (in terms of protein intake); (iii) the contribution of milk products to the family cash flow to cover daily family and farm expenses; and (iv) the medium- or long-term viability of the family farm. The long term viability of the farm is based on land assets per family worker and the total farm capital (physical assets, namely land and livestock) per child (which provided an indicator regarding the capacity of transmissibility of a viable farm to the next generation). In this way, we assumed that well-being was mainly based on the satisfaction of family needs in the short term (daily cash and protein nutrients), medium-term (annual income), and long-term (transmissibility). Finally, the theme 'efficiency' represented the technical and economic performance of the whole farm and livestock 
Table 3

Variables related to the different dimensions of sustainability.

\begin{tabular}{|c|c|c|c|}
\hline Group name & Variable & Label & Thematic focus \\
\hline \multicolumn{4}{|l|}{ Diversification Theme } \\
\hline \multirow[t]{2}{*}{ Animal } & $\%$ animal cash flow/total family cash flow & Livestock receipt & Livestock diversification \\
\hline & Dairy products/total products & Dairy product & \\
\hline \multirow[t]{6}{*}{ Crop } & $\%$ forage crops area (per total cultivated area) & Fodder area & Crop pattern \\
\hline & $\%$ food crop area (per total cultivated area) & Annual crop area & \\
\hline & $\%$ cash crop area (per total cultivated area) & Cash crop area & \\
\hline & $\%$ tree area (per total cultivated area) & Tree area & \\
\hline & $\%$ wheat area (per total cultivated area) & Wheat area & \\
\hline & $\%$ maize area (per total cultivated area) & Maize area & \\
\hline \multirow[t]{4}{*}{ Labour } & Salaried workforce in the farm workforce & WAWU & Labour diversification \\
\hline & Salaried agriculture workers & AW_tot & \\
\hline & Family farm workers & FWU & \\
\hline & Farm employment (family and salaried workers) & AWU & \\
\hline \multicolumn{4}{|l|}{ Integration Theme } \\
\hline \multirow[t]{4}{*}{ Feed } & Purchased feed cost per TLU ${ }^{1}$ & Purchased feed cost & Feed provided and feed cost \\
\hline & Self-produced fodder cost per TLU & Produced fodder cost & \\
\hline & Cost of concentrate per TLU & Concentrate cost & \\
\hline & Stocking rate (TLU per fodder area) & Stocking rate & \\
\hline \multirow[t]{2}{*}{ Environmental sustainability } & Organic nitrogen supply/nitrogen supply & Organic nitrogen supply & Use of on- and off-farm manure \\
\hline & On-farm nitrogen supply/ organic nitrogen supply & On farm organic nitrogen & \\
\hline \multicolumn{4}{|l|}{ Well-being Theme } \\
\hline \multirow[t]{7}{*}{ Income } & Annual net income & Net income & Monetary well-being \\
\hline & Annual net income/family workers & Net income per F worker & (medium term) \\
\hline & Annual net income/minimum salary ${ }^{2}$ & Net income par min. wage & \\
\hline & Annual net income per family member & Net income per capita & \\
\hline & $\%$ meat and milk income per total family and farm annual expenses & F expenses coverage & \\
\hline & Ruminant net income/minimum salary ${ }^{2}$ & & \\
\hline & & Ruminant income per min. wage & \\
\hline Food security & Protein supply/family protein needs & Protein supply & Food security \\
\hline Cash flow & $\%$ milk daily income/minimum family daily needs & Milk daily receipt & Monetary poverty indicator (short term) \\
\hline \multirow[t]{2}{*}{ Transmissibility } & Area by family work unit (in full-time job) & Area per F worker & Viability and transmissibility \\
\hline & Total physical capital per child & Capital per child & \\
\hline \multicolumn{4}{|l|}{ Efficiency Theme } \\
\hline \multirow[t]{2}{*}{ Crop and farm efficiency } & Net income per unit area & Net income_area & Economic efficiency \\
\hline & Profit & Profit & \\
\hline \multirow[t]{4}{*}{ Livestock efficiency } & Milk and meat income/livestock capital value & Bovine income & Technical efficiency \\
\hline & Feed cost per litre & Feed cost per litre & \\
\hline & Milk yield (litre/year/head) & Milk yield & \\
\hline & Milk produced per unit area & Milk product per area & \\
\hline
\end{tabular}

system in regards to the principal capital, i.e., land, livestock, and family workers.

\subsubsection{Multiple factor analysis}

We used multiple factor analysis or MFA (Escofier and Pagès, 1994) to study the relationships between several groups of variables. We were interested in the links between family and farm assets (represented by the themes of 'family,' 'land,' and 'livestock' systems; Table 2) and the four dimensions of sustainability, i.e., the degree of diversification, integration, efficiency, and well-being (Table 3). The MFA was carried out with a qualitative set of variables. The initially quantitative variables were preliminarily recoded into categorical variables.

The MFA is a factor analysis in which each variable is weighted according to its membership of a defined group of descriptors. The objective of MFA is to search for a new set of independent variables (factors) that are formally linear combinations of the primary variables calculated in such a way that they synthesize the maximum of the original variance. Thus, from a small number of factors, one obtains syntheses of similarities between individuals, links between variables, and links between groups of variables and factors.

The MFA's originality lies first on the variables' weighting based on their belonging group. This process is essential to balance the influence of each variable in the analysis. We have chosen to apply the weighting $1 / \sqrt{ } \lambda_{k}{ }^{1}$ where $\lambda_{k}{ }^{1}$ is the first eigenvalue associated with the factor analysis of the $k$-group table $(k=1, \ldots, K$; $\mathrm{K}$ is the number of groups of variables). This weighting removes the drawback that a group can have too much influence on the calculation of the factors. Thus, the variance of each group of variables is standardized and varies between 0 and 1 . The structure of the links between variables belonging to the same group is preserved and, the MFA is then interpreted as a classical factorial analysis. The second originality of the MFA is that the resulting factors can be seen as common dimensions of the groups of variables in the sense that it provides an optimal representation of separated factorial analyses of each group of variables (Pagès, 2004). In other words, two groups of variables (e.g., family asset and degree of diversification) will be related if two farms that are close in one group are also close in the other group of variables. A typology of variables' groups can be elaborated by calculating the measure of the link between a group of variables and each MFA's factor.

We can visualize factor by factor the proximities of these link measures, which are represented by group points on the inter-structure graph. We noted this measure $L g(0 \leq L g \leq 1)$, that corresponds to the contribution of each set of variables to the total variance. $L g$ is calculated by measuring the correlation between the variables $v_{k}$ in variable group $k$, and the MFA factor of rank $\alpha$ noted $z_{\alpha}$, which geometrically corresponds to the calculation of a projected variance:

$L_{g}\left(z_{\alpha}, v^{k}\right)=\sum_{k=1 \ldots K}$ projected variance of $v^{k}$ on $z_{\alpha}$

In sum, the MFA allowed the identification of a hierarchy of descriptor groups in the differentiation of crop-livestock farming systems. We focused on the results of the inter-structure, which provided a typology for the role of themes (Table 3 ) in the typology of farms (Table 2). All calculations were performed using $\mathrm{R}$ software ( $\mathrm{R}$ core 
Table 4

Variables used in the indicator assessment tool.

\begin{tabular}{|c|c|c|c|}
\hline Group & Variables & Label & Transformation for TATALE ${ }^{\mathrm{a}}$ \\
\hline \multicolumn{4}{|l|}{ Diversification theme } \\
\hline \multirow{2}{*}{ Animal } & $\%$ animal cash entries per total family cash entry & Livestock receipt & LCLI \\
\hline & Dairy products per total products & Dairy product & LCLI \\
\hline \multirow[t]{6}{*}{ Crop } & $\%$ area cultivated with fodder & Fodder area & LCLI \\
\hline & Food crops & Annual crop area & LCLI \\
\hline & Cash crops & Cash crop area & LCLI \\
\hline & Trees & Tree area & LCLI \\
\hline & Wheat & Wheat area & LCLI \\
\hline & Maize & Maize area & LCLI \\
\hline \multirow[t]{2}{*}{ Labour } & Number of salaried agriculture workers per land unit & External workers & LCLI \\
\hline & Number of family farm workers per total farm workers & Family workers & LCLI \\
\hline In $-/$ off-farm & Off-farm income per total family income & Off-farm income & LCLI \\
\hline \multicolumn{4}{|l|}{ Integration theme } \\
\hline \multirow[t]{4}{*}{ Feed } & Purchased feed cost per TLU ${ }^{\mathrm{b}}$ & Purchased feed cost & $\mathrm{CCCD}$ \\
\hline & Self-produced fodder cost per TLU & Produced fodder cost & LCLI \\
\hline & Concentrate cost per TLU & Concentrate cost & LD \\
\hline & Stocking rate (TLU per fodder area) & Stocking rate & LD \\
\hline \multirow{2}{*}{ Environmental sustainability } & Organic nitrogen supply/nitrogen supply & Organic nitrogen supply & LI \\
\hline & On-farm organic nitrogen per total nitrogen & On farm organic nitrogen & LI \\
\hline \multicolumn{4}{|l|}{ Well-being theme } \\
\hline \multirow{4}{*}{ Income } & Net income per family worker & Net income per F worker & LI \\
\hline & Net income per family member & Net income per capita & LI \\
\hline & $\%$ animal receipt per total family expenses per year & F expenses coverage & LI \\
\hline & Ruminant net income per minimum annual salary & Ruminant income per min. Wage & LI \\
\hline Food security & Protein supply/family protein needs & Protein supply & LI \\
\hline Cash flow & $\%$ milk daily receipt/family daily needs & Milk daily receipt & LI \\
\hline \multirow[t]{2}{*}{ Transmissibility } & Area by family work unit (Full-time job) & Area per F worker & LI \\
\hline & Total physical capital per child & Capital per child & LI \\
\hline \multicolumn{4}{|l|}{ Efficiency theme } \\
\hline \multirow[t]{4}{*}{ Ecological efficiency at farm level } & Net income per unit area & Net income_area & LI \\
\hline & Profit & Profit & LI \\
\hline & Total farm employment & AWU & LCLI \\
\hline & $\%$ salaried workforce in the farm workforce & WAWU & CCCD \\
\hline \multirow[t]{4}{*}{ Technical efficiency at livestock system level } & Milk/meat income/livestock capital & Bovine income & LI \\
\hline & Feed cost per litre & Feed cost per litre & LD \\
\hline & Milk yield (milk volume per head per year) & Milk yield & LI \\
\hline & Milk product per unit area & Milk product per area & LI \\
\hline
\end{tabular}

\footnotetext{
a L - linear; C - constant; D - decreasing; I - increasing.
}

b $\mathrm{TLU}=$ total livestock unit.

team, 2018) and the additional package FactomineR (Le et al., 2008).

\subsubsection{Multi-criteria assessment}

In the multi-criteria assessment approach, we used an indicator assessment tool, called TATALE, to calculate scores for the five themes (including scores for the sub-indicators of diversification, integration, efficiency, and well-being, and the overall score, i.e., sustainability). This tool has been developed and tested to assess multiple ecosystem services from grasslands (Taugourdeau et al., 2016; Johansen et al., 2016; Taugourdeau and Messad, 2017) using quantitative and qualitative variables.

In the first step, the tool normalizes the variables through scores that vary between 0 and 1 . To this end, the user chooses among different options for transforming the primary criteria (here variables) in score, according to the observed positive or negative contributions of the variables to the level of sustainability (i.e., diversification, integration, well-being, and efficiency), based mainly on expert knowledge (Table 4). For example, the variable related to the monetary contribution of activities to well-being can follow a linearly increasing function that represents an increase in well-being and then economic sustainability with this variable. Other criteria like crop allocation require a more complex form, knowing that diversification increases with the introduction of a new category of crops, becomes stable, then decreases when this crop represents more than the majority of the cultivated land, indicating a trend of specialization. We also have criteria like the purchased feed cost that follow a step function with an increase or decrease in the score per interval. Fig. 3represents the transformation of each variable in score.

In the second step, the TATALE tool aggregates the transformed primary variables with a user-chosen weight to obtain scores (related to diversification, integration, well-being, and efficiency) and a final sustainability score (Fig. 4. Consequently, all these scores become standardized variables (ranging from 0 to 1 ), which results from the transformation and aggregation of the variables corresponding to the main criteria of sustainability. In our approach, we suppose that all the variables have the same weight. The assessment of the different roles of livestock consisted of analyzing the average values and variabilities associated with the five geographical areas and the types of land access of the farmer (three types of access to the land, distinguishing beneficiaries, graduates, and new buyers).

\section{Results}

\subsection{Multiple factor analysis}

Fig. 5) represents the proximities between the groups of variables linked with the human and physical assets and the four dimensions of sustainability. The proximity of two 'themes' reveals some linear correlational links between the two groups of variables under these themes. Firstly, we can observe different positions of the livestock profile (stocks and species) by area. If the livestock asset constitutes a dominant factor of differentiation in El Nahda and Tiba, it appears as a 

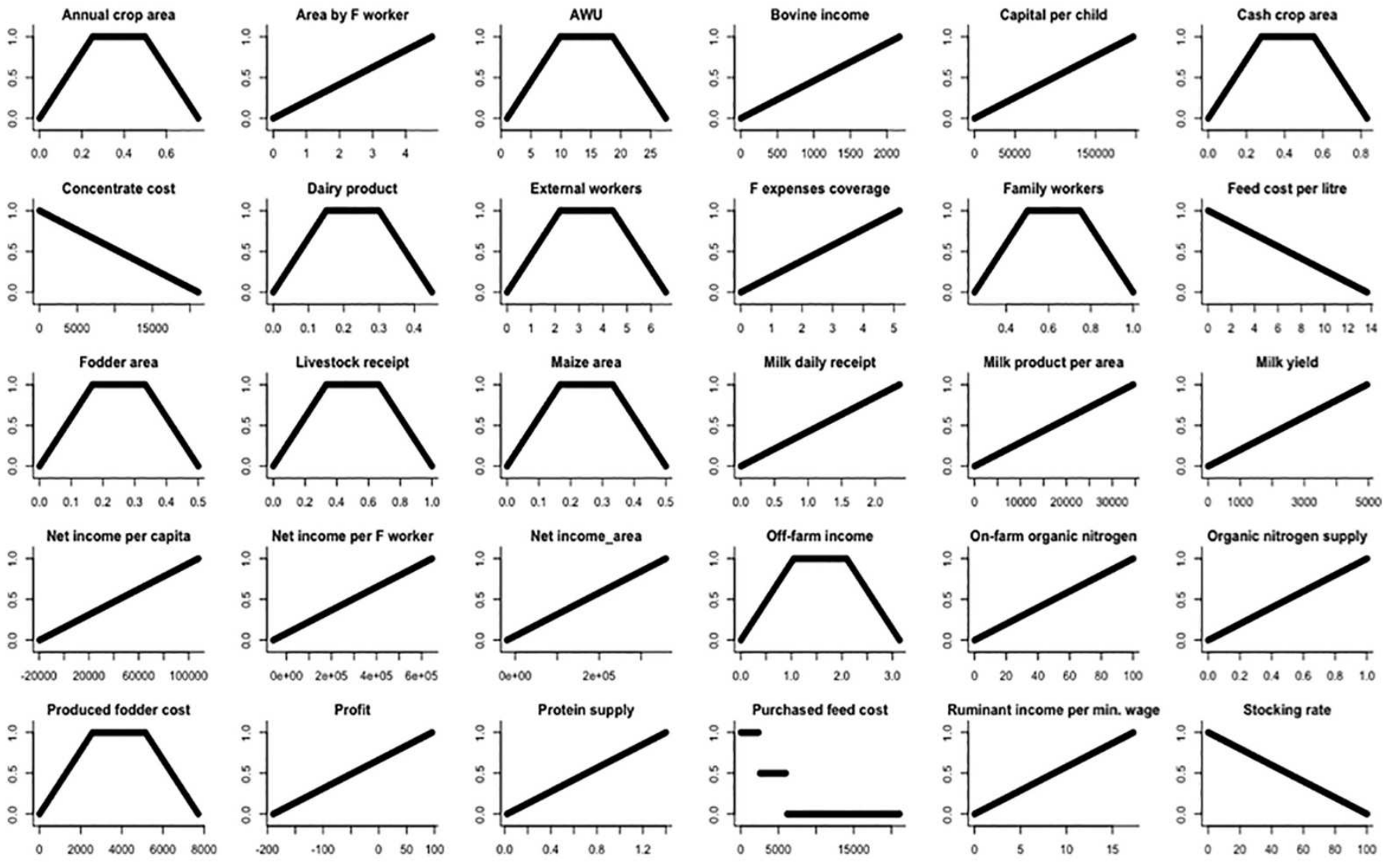
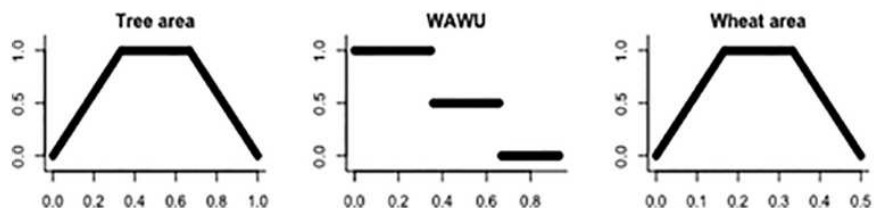

Fig. 3. Transformation of each variable's score (abscissa = raw value of the variable and the ordinate, i.e., the value of the associated score). Note: Null values for Feed cost per litre and Milk product per area were not taken into account because they correspond to farmers who do not produce milk; the variables are described in Tables 2 and 3 with their unit of value.

less discriminant factor in El-Hamman, Bustan, and Banger. In the two latter areas, we observed proximity between livestock and land asset because of the land constraint that conditioned the herd size. However, in Banger, efficiency and well-being increased with the degree of integration (mainly the criteria of feed purchased vs. that produced in the total feed supply). In contrast, in Bustan, well-being was linked mostly to the economic efficiency related to the crop system.

There were also two different trends in the differentiation of the population between El Nahda and Tiba, linked with the livestock asset. Whereas 'livestock' constitutes a significant factor of differentiation (represented mainly in the first axis) in the two areas, it is mainly linked to well-being and efficiency in El Nahda (with high technical performance) and diversification in Tiba. This result reflects the different roles of livestock between the two areas. In Tiba, livestock constitutes a transitional role of diversification (through investment) in the first years of settlement that corresponds to the settlement period of the family (housing) and the establishment of tree plantations. Once tree plantations become productive, the farmers reduce (or even abandon) the livestock. In El Nahda, animal rearing is a critical agricultural activity alongside seasonal crop activities and constitutes an essential source of revenue in the farm, according to 'animal stock.' In Tiba, we also observed the proximity of land access and family. The settlement policy can explain the closeness between 'land' and 'family' in these new lands that granted 2.1 ha to graduates, compared to 1.05 ha to the non-graduates beneficiaries. This land attribution constituted the second axis of differentiation in the Tiba area.

In Fig. 5, of note is the specific profile of the El Hamman area, where land assets contributed weakly to the efficiency and well-being of the family farms because of the high uncertainty regarding water availability. In this context, farmers have to diversify, notably with livestock activities, to improve the efficiency and well-being of the whole agricultural system. Moreover, in link with the cultural or geographical proximity of the settlers to the Bedouin territory, the farmers of this area diversified their livestock system with small and large ruminants.

The results obtained per type of beneficiary showed that for all new settlers, livestock was a priority as a contributing factor to the integration and diversification, through legume production, such as berseem (Fig. 6). Berseem (Trifolium alexandrinum) is crucial for developing and maintaining soil fertility in such a desert environment. We note that the distance between the variables' groups 'livestock' and 'efficiency' is the most important for the group 'new buyers,' for whom criteria related to the use of nitrogen were discriminant, but not always associated with livestock. Otherwise, the distance between 'livestock' and 'efficiency' or 'well-being' varied according to each type. For the non-graduates beneficiaries, here identified as 'Beneficials prog old renter', rapidly adopted mixed crop-livestock systems, in which the livestock was mainly a factor of integration and diversification. However, the primary source of income came from the crop system. For the 'Graduates' group, observing the link between livestock and efficiency, their entire well-being was mainly based on economic performance per 


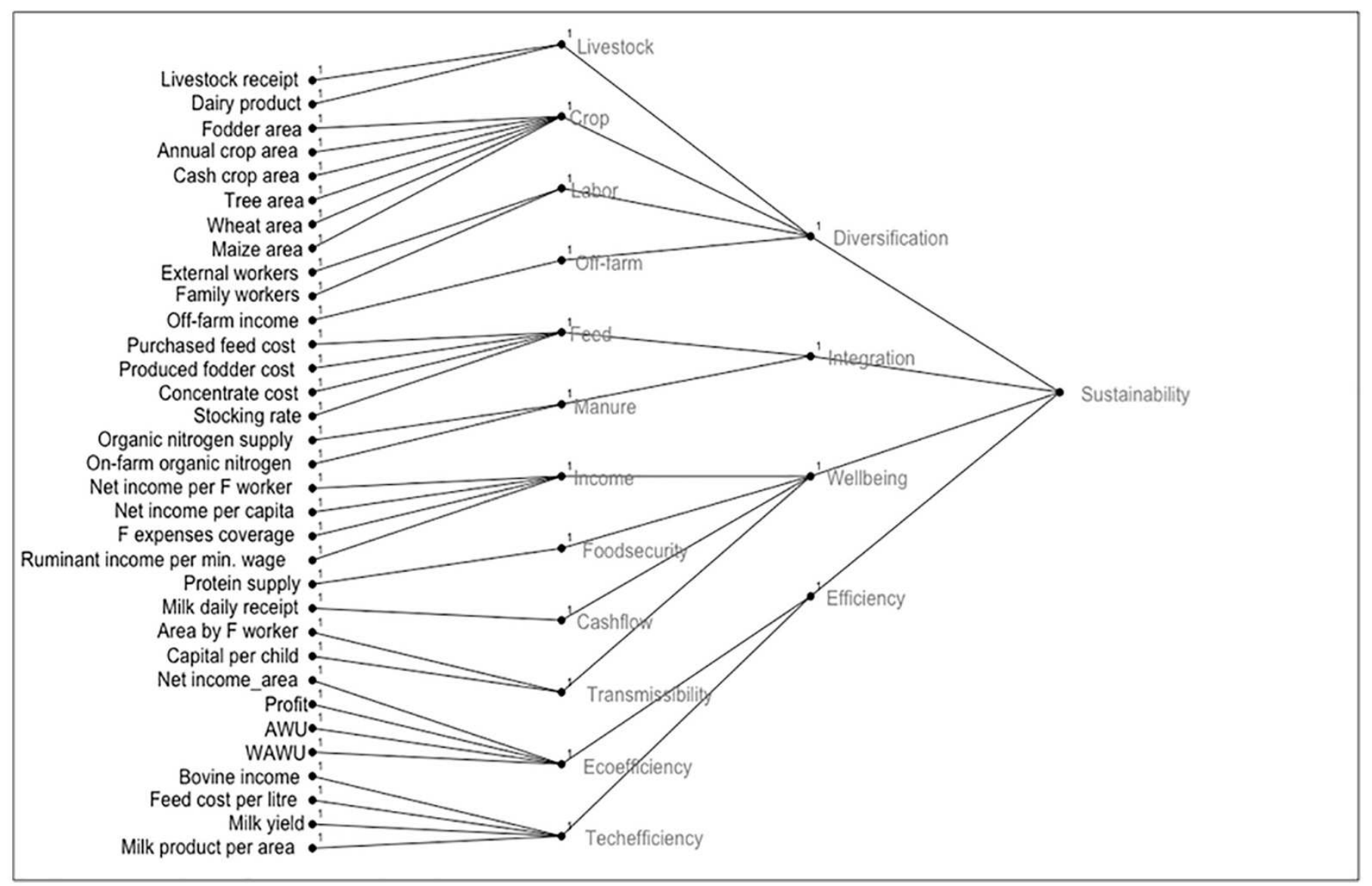

Fig. 4. Pathway of aggregation from the variables to the aggregated indicators of sustainability.

unit of land.

In summary, Fig. 7 shows the overall proximity or lack thereof between the different groups of variables, reflecting the structure of the population. We can identify four types of linear relationships among the aggregated factors. Firstly, there is an interrelationship between animal stock ('Livestock') and technical efficiency ('Techefficiency'), with an effect on family income ('Income'). Secondly, we can observe linear relationships between the daily milk cash-flow ('cashflow'), the long term viability ('Transmissibility'), and the family food security (based on the coverage of family protein needs). A third relationship was among overall sustainability with diversification and integration (mainly based on manure use). We also noted a fourth link between the diversification of activities outside the farm ('Off-farm') and farm labor organization ('Labor') (with the variable 'employment of outside workers'). This representation facilitated the differentiation of two profiles for family farm development on the second axis, the on-farm and off-farm diversified systems oriented to a strategy of labor productivity, and the crop-livestock systems oriented to a strategy of farm reproduction at medium and long terms. We also observed that livestock was more significant in the second profile, due to its role in increasing capital transmissibility and food security based on protein intake.

\subsection{Multi-criteria assessment of the sustainability of the crop-livestock systems}

Fig. 8 shows the relative scores for sustainability by area and type of land access. The lowest score was for the graduated settlers in the Tiba area. In contrast, the highest was for highly-integrated crop-livestock systems in the oldest cultivated lands of our studied area (El Nahda), where farmers have been cultivating their land for the last 50-60 years.
In the El Hamman area, despite the development of livestock activity, the overall sustainability of the system remained low. We observed the intermediary positions of Bustan and Banger, where mixed crop-livestock systems were dominant, but with small herd sizes because of land constraints and remoteness, the latter restraining milk marketing valorization.

Fig. 9 details the main factors behind sustainability. First, integration was a common impacting factor on sustainability for all areas and categories of landowners. Second, the degree of integration explained the gap of the overall sustainability index among farm systems in the most recent settled areas (mainly in Tiba and Banger areas) compared to that of the oldest ones (El Nahda). Notably, this gap was mostly due to the different roles of livestock in terms of nitrogen supply. In the Tiba area, the farmers were replacing the traditional crop systems, based on wheat and berseem in winter and vegetables and maize in summer, with tree plantations. This tree-specialization, with the abandonment of livestock activities and, consequently, a decrease in both integration and diversification, affected the entire sustainability of the system.

Moreover, with livestock destocking, the ratio of the on-farm nitrogen supply was the lowest, and farmers were obliged to buy bovine or poultry manure. This phenomenon is also illustrated in Fig. $9 \mathrm{~b}$ for the graduates' group, mainly represented in the Tiba area. Integration had the highest score for the other beneficiaries that represented the majority of settlers in the El Nahda areas and, to a lesser extent, in the Bustan area.

We also observed a little differentiation in the sustainability index of the systems according to the indicators of technical or economic performance, and then the global well-being of the family farms. Notably, the areas of El Nahda or Tiba with the highest level of specialization and productivity did not reach higher well-being scores. This result can be explained by the way in which the well-being indicator was 

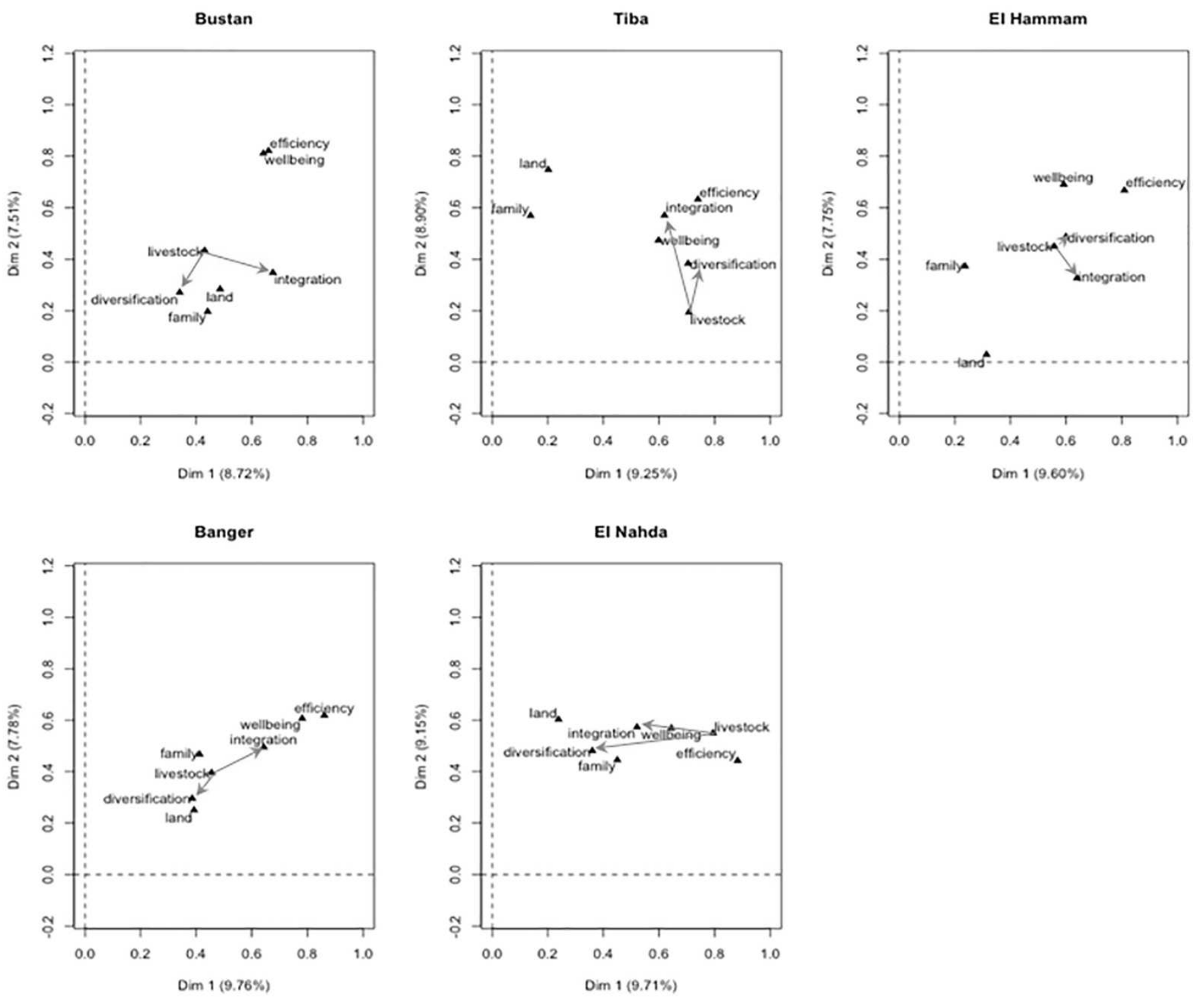

Fig. 5. Interaction between family farm assets (family, land, and livestock) and sustainability indicators related to diversification, integration, efficiency, and wellbeing for the five selected areas in the western part of the Nile Delta (Egypt). Representation of the MFA projected variance of the groups of variables in the factorial map (Dim 1 x Dim 2).

designed, which gives as much weight to food security and cash flow in diversified systems in link with the self-consumption of animal products and daily receipt from milk satisfaction of needs as to income.

Overall, we can observe a relative homogeneity of profiles of sustainability in terms of the relative contribution of the four studied dimensions in the zone. If livestock contributed significantly to farm efficiency and well-being in the El Nahda and Tiba areas in 2014, we noted different profiles. In the Tiba area, the central role of livestock consisted of funding the agricultural and family investment over the first few years of settlement, mainly for housing expenses or tree plantation (Alary et al., 2018). As soon as tree plantation became productive, livestock contributed slightly to the diversification and well-being at the farm level. Conversely, in the El Nahda area, animal rearing remained a significant activity in increased well-being and efficiency because of its technical performance. From these orientations, we observed different scores regarding sustainability, in link with the degree of integration. The tree-specialized system in the Tiba area had the lowest sustainability score. These results confirmed the high environmental vulnerability of specialized systems that we observed at the edge of the Mediterranean (Alary et al., 2019).
In the Banger and Bustan areas, the limited access to land explained the degree of diversification toward livestock. In these two areas, efficiency and well-being were related to the degree of integration through the feed system and manure management. These systems reflected the traditional agricultural systems that were operational in the majority of the irrigated lands of the Nile Valley. However, in contrast to that of the Banger area, well-being in the Bustan area was mainly based on the variables of efficiency, especially the technical performance of livestock linked with the experience of settlers coming from the old lands.

Finally, we noted that the gap between diversification and efficiency scores increased progressively from Banger to El Nahda, Bustan, El Hamman, and Tiba, and this in the same trend as the overall sustainability score. Thus, diversification might have a more substantial impact on the sustainability score than the efficiency indicators, which were based on the technical performance of the livestock system and the overall revenue per unit area. This questions the current agricultural policies oriented toward productivity per capital and specialization on the NRLs. Diversification of farming systems may have more effects on the overall sustainability. This diversification, mainly embedded in the livestock activities in these remote zones, confirmed the 

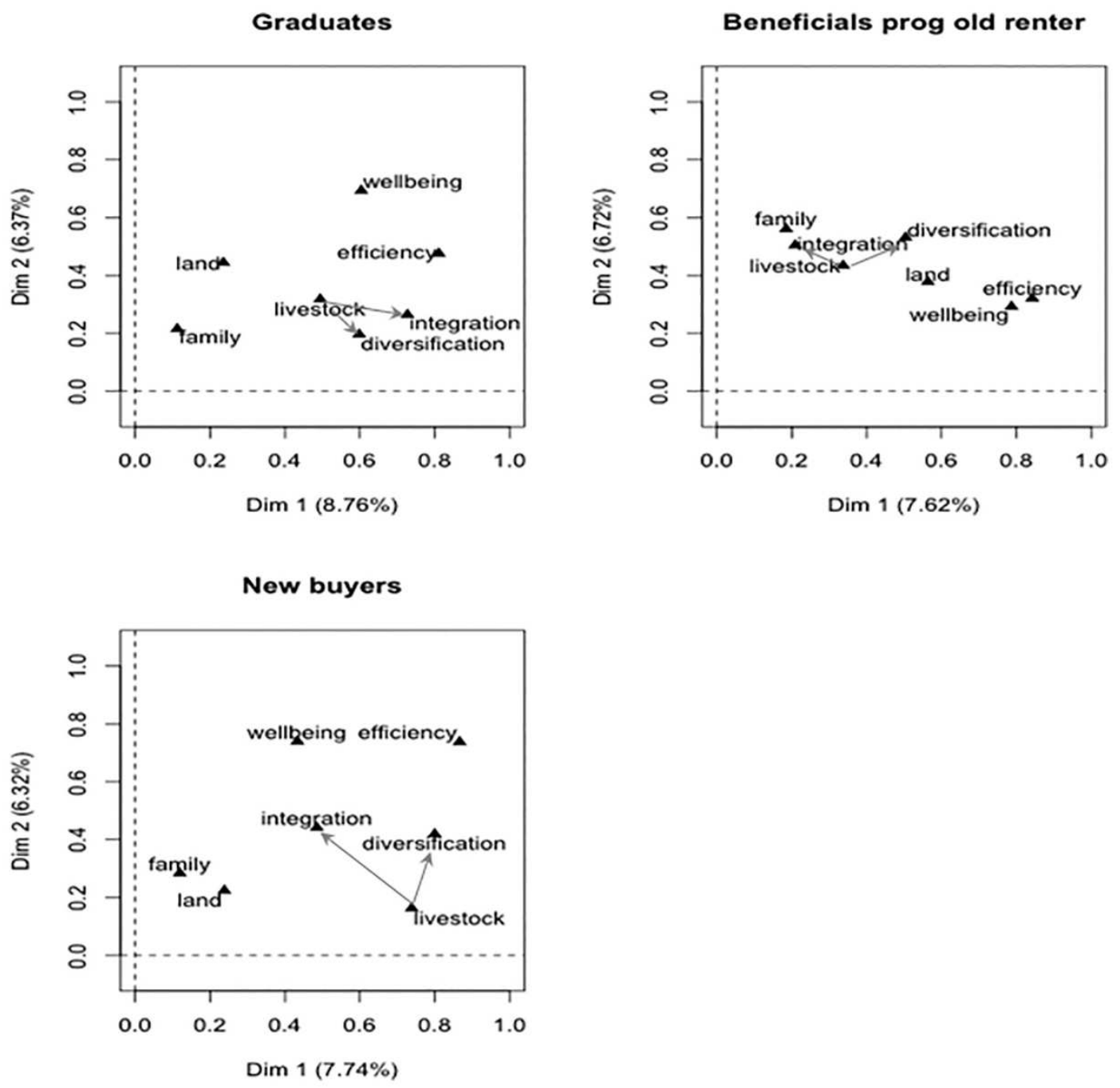

Fig. 6. Interaction between family farm assets (family, land, and livestock) and sustainability indicators related to diversification, integration, efficiency, and wellbeing for the three types of land beneficiary in the western part of the Nile Delta (Egypt). Representation of the MFA projected variance of the groups of variables in the factorial map (Dim $1 \times$ Dim 2).

crucial role of livestock on the development of sustainable systems. For agricultural development in these newly reclaimed desert areas, these results must challenge the Egyptian government's policies that, up to this date, privileged cash crop models at the detrimental to integrated crop-livestock models.

\section{Discussion}

The factor analysis based on the primary criteria (with no transformation in their scores) allowed the identification of links or their absence among the different groups of variables representing the four studied dimensions of sustainability, i.e., diversification, integration, efficiency, and well-being. These links approached by linear correlation coefficients reflect simple correlational relationships. A correlational relationship states that two things perform in a synchronized or similar manner, without causal effect evidence. For instance, we often describe the relationship between the livestock asset and the land asset in a context of limited land access. Still, we need a third variable problem, such as feed requirement or feed cost, to explain causal relationships. With this method, the type of relationships reflects the logic or function based on the processes through which the outcomes are brought into being from the productive factors in the entire farm system. In the study, this approach allowed for highlighting different contributions of livestock to the four identified dimensions of sustainability. Notably, the results show the significant contribution of livestock activity in increasing efficiency in the more intensive farms, compared to the other areas where livestock, through the home-consumption and saving function, secure the family assets and improve the overall well-being of these families. So this approach reveals different combinations of activities and resources of family farms in their achievement of socioeconomic viability (well-being) and sustainable management of resources (efficiency). In this way, this method allows for identifying causal or correlational processes regarding the relative weight and relations of factors to explain sustainability, but not for providing an assessment. Experience also revealed that reading the data of this method on a factor plan can be challenging for non-specialists.

Besides, the multi-criteria approach used herein, based on an indicator assessment tool (TATALE), offered a more comprehensive way of analyzing the relationships among the variables. The tree-of-relationships provided a clear structure for the causal effects that we assimilated with a path analysis (Wright Von Wright, 1971), allowing the assessment of known causal impact. In this case, we do not identify the causal effects, but rather the causal processes in the manner of Salmon (1984), as described by Campaner and Galavotti (2012). However, this approach supposes a high level of expertise in the functioning and trends of the studied systems to design the causal processes. In the present study, we opted not to weight the primary criteria, meaning that all were equivalent in assessing the sustainability 


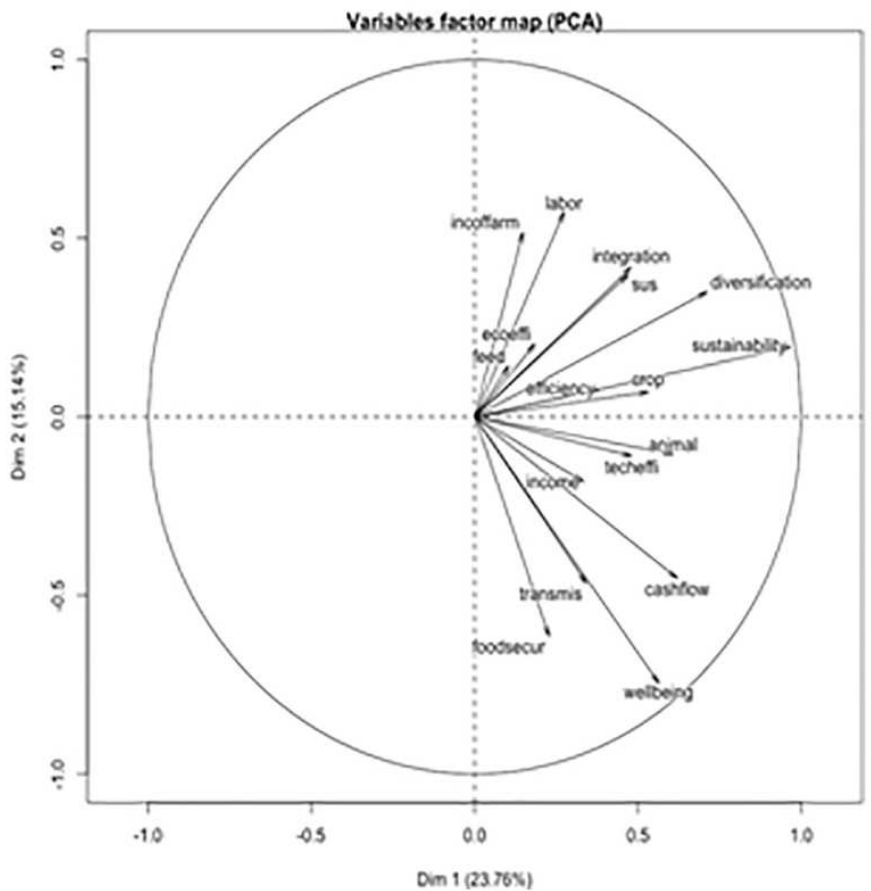

Fig. 7. Principal component analysis (PCA) factorial map of the scores from aggregated indicators of sustainability (all sub-indicators are described in Fig. 4)

indicator. This choice results from our posture to address the complexity of sustainability, including economic, social, and ecological dimensions that are both dependent and primordial in a sustainable process. Additionally, our goal was to assess the different effects of the four dimensions (i.e., integration, diversification, efficiency and wellbeing) in link with livestock activity, without privileging one or another dimension of the sustainability, and not necessarily in an optic to represent the whole sustainability. The results are highly relevant to describe and understand the different contribution of factors to the sustainability. In our established pathways, the results clearly show the high effect of crop-livestock integration on the overall sustainability of family farm systems. However, using this approach to understand the global sustainability of the whole farm system by considering all the activities requires a supplementary reflection in regards to the shapes and weightings of the primary criteria in concertation with the target group and do not necessarily have meaning for other groups of people or location and problem. In this last perspective, the shapes and weighting of criteria should result from a participatory process that includes different end-users or stakeholders and to run multiple analyses according to the multiple views of stakeholders.

Regarding the selected indicators, one of the originalities of this work was how the dimension of well-being has been approached in connection with the multiple contributions of the breeding activity in the short, medium, and long term security of families. This set of indicators allows considering the various roles of livestock in the overall socio-economic viability at the family farm level. This approach also enables us to distinguish the different priorities of farmers when articulating crop and livestock activities. More generally, for the two methods, the choice of primary criteria was critical, constituting the first level of the hypothesis.

\section{Conclusion}

In summary, the first factor-based approach aims at analyzing the similarities and differences among several sets of variables to compare household populations, balancing their weights related to the number of variables and their thematic heterogeneity. The multi-criteria assessment approach offers an easy way to aggregate a multitude of criteria collected at the farm and local level, whatever the size of the sample or the location. In this sense, the TATALE tool could be promising for synthesizing expert knowledge and comparing different path analyses in the overall sustainability assessment that can be discussed through the factor analysis. However, it appears the necessity to conduct more in-depth studies with stakeholders/end-users on the choice of variables within each dimension of the sustainability that would reflect the manner of considering the entire system and, therefore, its durability. Also, the shaping and weighting of each variable that condition the final index of sustainability require high expert knowledge.

However, the use of the two methods allowed us to show the

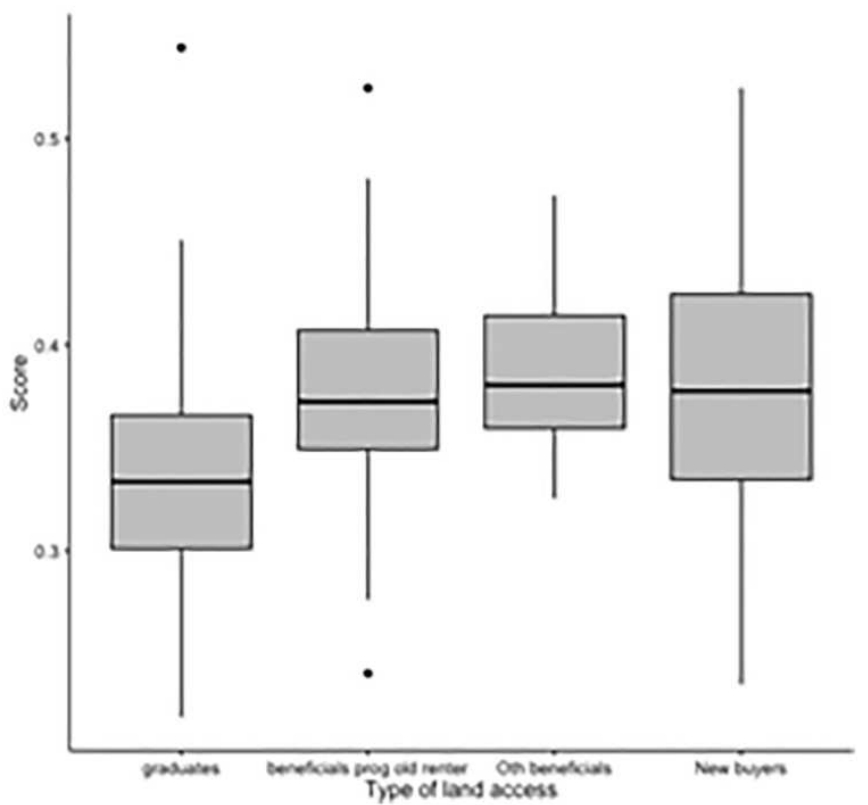

Fig. 8. Score distribution for sustainability, by area (a) on the left, and by type of land access (b)*. The median of the distribution is represented by the horizontal line in each box. The boxes represented $50 \%$ of the individuals. The limits given by the vertical lines on each end of the boxes represent approximately $95 \%$ of the distribution. 

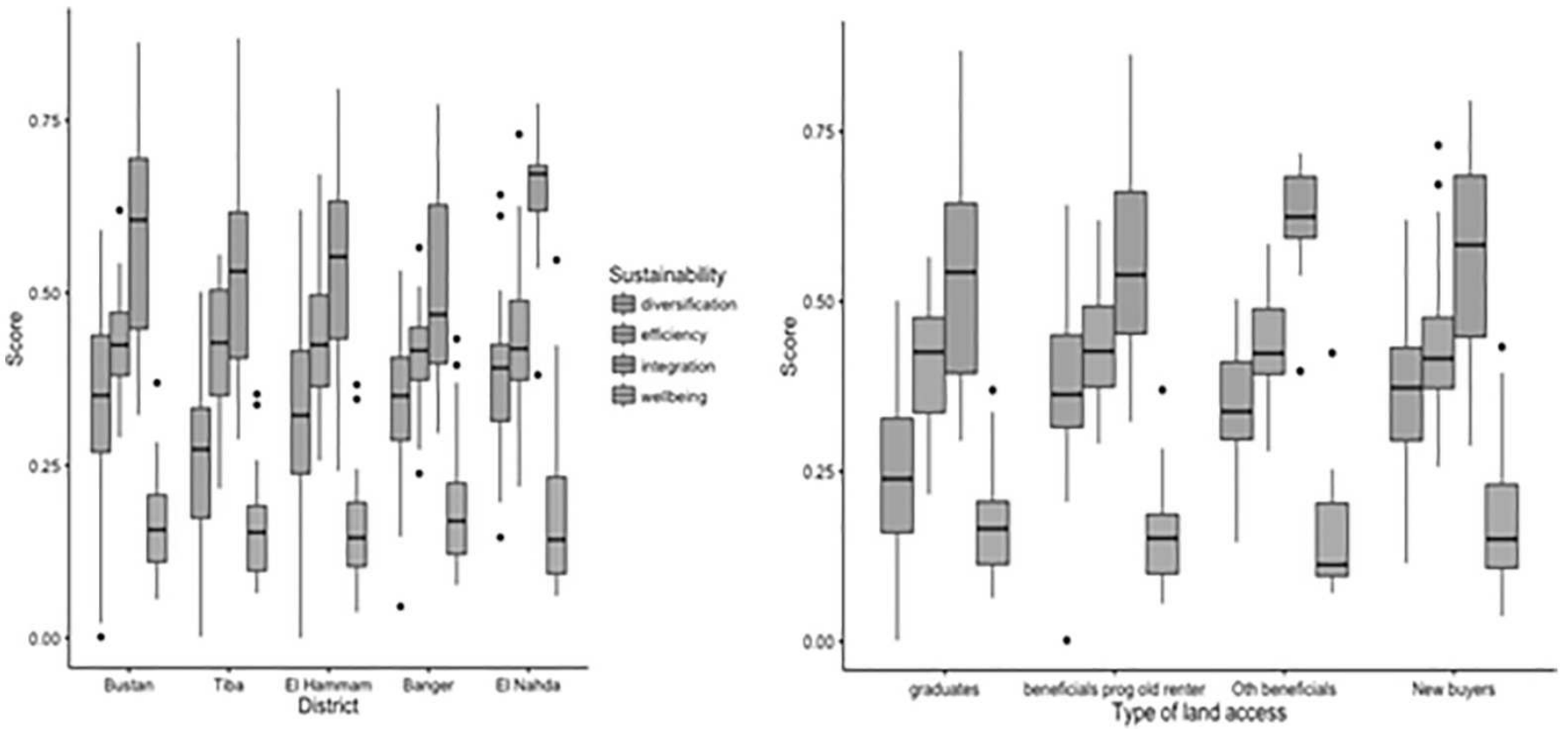

Fig. 9. Distribution of the scores of the sub-indicators related to diversification, efficiency, integration and well-being, by area (a), and by type of land access (b) (the median of the distribution is represented by the horizontal line in each box).

differentiated roles of livestock activities between diversification and integration, and consequently on efficiency and well-being achievement. Notably, we can say that the two approaches reveal similar trends in regards to the significant contribution of livestock to the farm efficiency in the newly reclaimed desert areas of Egypt (mainly through the manure supply for soil enrichment), but not necessarily to the socioeconomic viability that includes different components related to food security and income generation which are mainly supported by the diversification. More precisely, the results show that if livestock integration is at the core of agronomic and environmental sustainability through the leguminous fodder in the crop rotation and manure in this desert lands, livestock activities play different roles and functions regarding household living conditions, by either increasing household and farm investment or the labour productivity in the best-endowed family farms or ensuring a short and medium-term security for the more vulnerable family farms. Thenceforward, different angles regarding sustainability, focused on crop management or other social component of the well-being, for instance, would not have resulted in the same score for durability. In our case-study, these various functions of livestock consequently question the strategy of livestock development policies that should have a component-oriented on its preservation as a pillar of socio-economic and environmental sustainability of the rural areas in this desert lands. However, we have not considered the environmental effects of livestock in terms of methane or carbon dioxide that could have changed the overall impact of livestock on sustainability but implying a change of scale. So, if the set of criteria can be developed regarding the different objectives, the framework appears promising to have a global approach of sustainability with its various dimensions.

\section{Funding}

This work was supported by the Agency of National Research (ANR) in France (Grant ARIMnet Program 2011, ANR-2012-2015, 12-AGRI0007) and the CGIAR Research Program on Livestock.

\section{Declaration of Competing Interest}

The authors declare that there are no conflicts of interest.

\section{Acknowledgments}

The material presented here has been collected in the framework of a collaborative research project named CLIMED on 'The Future of Mediterranean Livestock Farming Systems: Opportunity and Efficiency of Crops-Livestock Integration', within the research program ARIMnet (2012-2016). In Egypt, this project is associated with CIRAD (Centre International de Recherche Agronomique pour le Developpement), INRA (Institute National de Recherche Agronomique), ICARDA (International Centre for Agricultural Research in the Dry Areas), and Egypt's Animal Production Research Institute (APRI). We especially thank all the researchers from APRI's sheep and goat research department for their active participation and all the farmers and stakeholders in the Nubaria area for the time they spent with us. For the present research paper, funding from the CGIAR Research Program on Livestock is acknowledged. The authors thank all donors and organizations who globally supported the work of the CGIAR Research Program on Livestock through their contributions to the CGIAR system.

\section{References}

Adriansen, H.K., 2009. Land reclamation in Egypt: a study of life in the new lands. Geoforum 40, 664-674. https://doi.org/10.1016/j.geoforum.2009.05.006.

Alary, V., Corniaux, C., Aboul Naga, A., Galal, S. (Eds.), 2016. Atlas of the Traditional Milk Sector around Grater Cairo in Egypt. CIRAD-ARC-APRI, Montpellier. http:// agritrop.cirad.fr/584660/ (82 p. ISBN 978-2-87614-724-9).

Alary, V., Aboul-Naga, A., Osman, M.A., Daoud, I., Abdelraheem, S., Salah, E., Juanès, X., Bonnet, P., 2018. Desert land reclamation programs and family land dynamics in the Western Desert of the Nile Delta (Egypt), 1960-2010. World Dev. 104, 140-153. https://doi.org/10.1016/j.worlddev.2017.11.017.

Alary, V., Moulin, C.H., Lasseur, J., Aboulnaga, A., Srairi, T., 2019. The dynamic of croplivestock systems in the Mediterranean and future prospective at local level: a comparative analysis for south and North Mediterranean systems. Livest. Sci. 224, 40-49.

Alvarez, S., Salgado, P., Vayssières, J., Guerrin, F., Tittonell, P., Bocquier, F., Tillard, E. 2010. Modelling crop-livestock integration systems at a farm scale in a highland region of Madagascar: a conceptual model. Adv. Anim. Biosci. 1 (2), 496-497. https://doi.org/10.1017/S2040470010001147.

Alvarez, S., Rufino, M.C., Vayssières, J., Salgado, P., Tittonell, P., Tillard, E., Bocquier, F., 2014. Whole-farm nitrogen cycling and intensification of crop-livestock systems in the highlands of Madagascar: an application of network analysis. Agric. Syst. 126, 25-37. https://doi.org/10.1016/j.agsy.2013.03.005.

Barnes, J., 2013. Expanding the Nile's watershed: The science and politics of land reclamation in Egypt. In: Mikhil, A. (Ed.), Water on Sand: Environmental Histories of the Middle East and North Africa. Oxford University Press, New York, NY, pp. 
$251-271$.

Berre, D., Corbeels, M., Rusinamhodzi, L., Mutenje, M.J., Thierfelder, C., Lopez-Ridaura, S., 2017. Thinking beyond agronomic yield gap: smallholder farm efficiency under contrasted livelihood strategies in Malawi. Field Crop Res. 214, 113-122. https://doi. org/10.1016/j.fcr.2017.08.026.

Bishay, A., 1993. The deserts of Egypt: Desert development systems. In: Craig, G.M. (Ed.), The Agriculture of Egypt. Oxford University Press, New York, NY, pp. 278-344.

Boyazoglu, J., 1998. Livestock farming as a factor of environmental, social and economic stability with special reference to research. Livest. Prod. Sci. 57, 1-14.

Bush, R., 2007. Politics, power and poverty: twenty years of agricultural reform and market liberalization in Egypt. Third World Q. 28 (8), 1599-1615. https://doi.org/ $10.1080 / 01436590701637441$.

Campaner, R., Galavotti, M.C., 2012. Evidence and the assessment of causal relations in the health sciences. Int. Stud. Philos. Sci. 26 (1), 27-45. https://doi.org/10.1080/ 02698595.2012.653113.

Carof, M., Colomb, B., Aveline, A., 2013. A guide for choosing the most appropriate method for multi-criteria assessment of agricultural systems according to decisionmakers' expectations. Agric. Syst. 115, 51-62. https://doi.org/10.1016/j.agsy.2012. 09.011.

Dixon, J., Li, X., Msangi, S., Amede, T., Bossio, D., Ceballos, H., Ospina, B., Howeler, R., Reddy, B.V.S., Abaidoo, R., Timsina, J., Crissman, C., Mares, V., Quiroz, R., LeonVelarde, C., Herrero, M., Blummel, M., Holmann, F., Peters, M., White, D., Qadir, M., Szonyi, J., 2010. Feed, food and fuel: Competition and potential impacts in small crop-livestock-energy farming systems. In: CGIAR Systemwide Livestock Programme Project Report. SLP, AddisAbaba, Ethiopia, (114 pp).

Ellis, F., 1998. Household strategies and rural livelihood diversification. J. Dev. Stud. 35 (1), 1-38. https://doi.org/10.1080/00220389808422553.

Ellis, F., 2000. The determinants of rural livelihood diversification in developing countries. J. Agric. Econ. 51 (2), 289-302. https://doi.org/10.1111/j.1477-9552.2000. tb01229.x.

Escofier, B., Pagès, J., 1994. Multiple factor analysis (AFMULT package). Comput. Stat. Data Anal. 18, 121-140. https://doi.org/10.1016/0167-9473(94)90135-X.

Faye, B., Alary, V., 2001. Les enjeux des productions animales dans les pays du Sud. INRA Prod. Anim 14 (1), 3-13.

Gerber, P.J., Steinfeld, H., Henderson, B., Mottet, A., Opio, C., Dijkman, J., Falcucci, A, Tempio, G., 2013. Tackling Climate Change through Livestock - a Global Assessment of Emissions and Mitigation Opportunities. Food and Agriculture Organization of the United Nations (FAO). http://www.fao.org/3/a-i3437e.pdf.

Goodman, L.A., 1961. Snowball sampling. Ann. Math. Stat. 32 (1), 148-170.

Herrero, M., Thornton, P.K., Notenbaert, A.M., Wood, S., Msangi, S., Freeman, H.A., Bossio, D., Dixon, J., Peters, M., van de Steeg, J., Lynam, J., ParthasarathyRao, P., Macmillan, S., Gerard, B., McDermott, J., Seré, C., Rosegrant, M., 2010. Smart investments in sustainable food production: revisiting mixed crop-livestock systems. Science 327, 822-825. https://doi.org/10.1126/science.1183725.

Herrero, M., Havlík, P., Valin, H., Notenbaert, A., Bufino, M.C., Thornton, P.K., Blümmel, M., Weiss, F., Grace, D., Obersteiner, M., 2013. Biomass use, production, feed efficiencies, and greenhouse gas emissions from global livestock systems. Proc. Natl. Acad. Sci. 110, 20888-20893.

Herrero, M., Wirsenius, S., Henderson, B., Rigolot, C., Thornton, P., Havlík, P., de Boer, I, Gerber, P., 2015. Livestock and the environment: what have we learned in the past decade? Annu. Rev. Environ. Resour. 40, 177-202.

Johansen, L., When, S., Taugourdeau, S., 2016. The effect of selected soil and climate parameters on multiple ecosystem services from abandoned and managed semi-natural grasslands. In: Höglind, M., Bakken, A.K., Hovstad, K.A., Kallioniemi, E., Riley, H., Steinshamn, H., Østrem, L. (Eds.), The Multiple Roles of Grassland in the European Bioeconomy. Proceedings of the 26th General Meeting of the European
Grassland Federation. European Grassland Federation-NIBIO, pp. 636-638 (Grassland Science in Europe, 21).

Kropps, I., Pouyan Nejadhashemi, A., Deb, K., Abouali, M., Roy, P.C., Adhikari, U., Hoogenboom, G., 2019. A multi-objective approach to water and nutrient efficiency for sustainable agricultural intensification. Agric. Syst. 173, 289-302.

Le, S., Josse, J., Husson, F., 2008. FactoMineR: an R package for multivariate analysis. J. Stat. Softw. 25 (1), 1-18. http://www.jstatsoft.org/v25/i01/.

Leterme, P., Nesme, T., Regan, J., Korevaar, H., 2019. Chapter 21 - environmental benefits of farm- and district-scale crop-livestock integration: A European perspective. In: Lemaire, G., De Faccio Carvalho, P.C., Kronberg, S., Recous, S. (Eds.), Agroecosystem Diversity. Academic Press, pp. 335-349. https://doi.org/10.1016/B978-0-12811050-8.00021-2.

Malm, A., Esmailian, S., 2012. Ways in and out of vulnerability to climate change: abandoning the Mubarak project in the northern Nile Delta, Egypt. Antipode 45 (2), 474-492. https://doi.org/10.1111/j.1467-8330.2012.01007.x.

Matson, P.A., Parton, W.J., Power, A.G., Swift, M.J., 1997. Agricultural intensification and ecosystem properties. Science 277 (5325), 504-509. https://doi.org/10.1126/ science. 277.5325.504.

Nielsen, T.T., Adriansen, H.K., 2005. Government policies and land degradation in the Middle East. Land Degrad. Dev. 16 (2), 151-161. https://doi.org/10.1002/ldr.677.

Pagès, J., 2004. Multiple factor analysis: Main features and application to sensory data. Revista Colombiana de Estadística 27.

R Core Team, 2018. R: A Language and Environment for Statistical Computing. R Foundation for Statistical Computing, Vienna, Austria. ISBN 3-900051-07-0. http:// www.R-project.org/.

Reardon, T., Delgado, C., Matlon, P., 1992. Determinants and effects of income diversification amongst farm households in Burkina Faso. J. Dev. Stud. 28, 264-296. https://doi.org/10.1080/00220389208422232.

Reardon, T., Taylor, J.E., Stamoulis, K., Lanjouw, P., Balisacan, A., 2000. Effects of nonfarm employment on rural income inequality in developing countries: an investment perspective. J. Agric. Econ. 51 (2), 266-288. https://doi.org/10.1111/j. 1477-9552.2000 tb01228.x.

Salmon, W., 1984. Scientific Explanation and the Causal Structure of the World. Princeton University Press, Princeton, NY. https://doi.org/10.2307/2185459.

Srairi, M.T., Ghabiyel, Y., 2017. Coping with the work constraints in crop-livestock farming systems. Ann. Agric. Sci. 62, 23-32. https://doi.org/10.1016/j.aoas.2017. 01.001.

Steinfeld, H., Gerber, P., Wassenaar, T., Castel, V., Rosales, M., de Haan, C., 2006. Livestock's Long Shadow (Report). FAO. http://www.fao.org/3/a-a0701e.pdf.

Taugourdeau, S., Messad, S., 2017. TATALE: Tools for Assessment with Transformation and Aggregation Using Simple Logic and Expertise. Manual (Version March 2017). Montpellier: CIRAD-ES-UMR SELMET. 11 pp. http://umr-selmet.cirad.fr/lesproduits-et-expertises/produits/tatale.

Taugourdeau, S., Johansen, L., Wehn, S., 2016. Assessment of multiple ecosystem services of Norwegian semi-natural grasslands based on vegetation characteristics. In: EcoSummit 2016 - Ecological Sustainability: Engineering Change. Institut National de Recherche Agronomique, Institut de Recherche pour le développement, Montpellier (s.n., poster).

Tittonell, P., 2014. Ecological intensification of agriculture - sustainable by nature. Curr. Opin. Environ. Sustain. 8, 53-61. https://doi.org/10.1016/j.cosust.2014.08.006.

Von Wright, G., 1971. Explanation and Understanding. Cornell University Press, New York, NY.

Wirén-Lehr, Von, 2001. Sustainability in agriculture-an evaluation of principal goaloriented concepts to close the gap between theory and practice. Agric. Ecosyst. Environ. 84, 115-129. https://doi.org/10.1016/S0167-8809(00)00197-3. 
